\title{
Kualitas Pelayanan Fiskus, Dimensi Keadilan, Kesadaran Wajib Pajak dan Kepatuhan Wajib Pajak Orang Pribadi
}

\author{
Pipit Awwalina Farihin Yadinta ${ }^{1}$, Suratno ${ }^{2}$, JMV Mulyadi ${ }^{3}$ \\ ${ }^{1.2 .3}$ Universitas Soedirman, Jl. Srengseng Sawah, Jagakarsa, Jakarta Selatan, 12640
}

\section{INFO ARTIKEL}

JEL Classsification:

H24

H21

Keywords:

tax compliance, tax awareness, tax justice, tax authorities services

\section{ABSTRACT}

This study aims to test and analyze empirically the effect of tax authority service quality, justice dimensions and taxpayer awareness on individual tax compliance. A common problem in this study is that the level of mandatory compliance in Tax Service Office in Depok has fluctuated every year. The population in this study is an individual taxpayer in Tax Service Office Depok. Until the end of 2015 there were 241,518 active taxpayers. Sampling is done by proportional sampling method. The number of samples is determined by 110 people. The primary data collection method used is the questionnaire method. The data analysis technique used in this study is multiple regression analysis techniques. Based on the results of the analysis conducted, evidence was obtained that the quality of service of the tax authorities, the dimensions of justice and awareness of taxpayers had a significant positive effect on individual tax compliance.

\begin{abstract}
ABSTRAK
Penelitian ini bertujuan untuk menguji dan menganalisis secara empiris pengaruh kualitas pelayanan fiskus, dimensi keadilan dan kesadaran wajib pajak terhadap kepatuhan pajak orang pribadi. Permasalahan umum dalam penelitian ini adalah tingkat kepatuhan wajib di KPP Depok mengalami fluktuatif naik turun setiap tahunnya. Populasi dalam penelitian ini adalah para wajib pajak orang pribadi yang ada di KPP Depok. Sampai dengan akhir tahun 2015 tercatat sebanyak 241.518 wajib pajak aktif. Pengambilan sampel dilakukan dengan metode proportional sampling. Jumlah sampel ditentukan 110 orang. Metode pengumpulan data primer yang dipakai adalah dengan metode angket. Teknik analisis data yang digunakan dalam penelitian ini adalah teknik analisis regresi berganda. Berdasarkan hasil analisis yang dilakukan diperoleh bukti bahwa kualitas pelayanan fiskus, dimensi keadilan dan kesadaran wajib pajak memiliki pengaruh positif yang signifikan terhadap kepatuhan pajak orang pribadi.
\end{abstract}

\section{Pendahuluan}

Peran serta wajib pajak dalam sistem pemungutan pajak sangat menentukan tercapainya target penerimaan pajak. Penerimaan pajak yang optimal dapat dilihat dari berimbangnya tingkat penerimaan pajak aktual dengan penerimaan pajak potensial atau tidak terjadi tax gap. Besarnya tax gap mencerminkan tingkat kepatuhan membayar

*Email Korespondensi: 'pit_yadinta@yahoo.com 
pajak (tax compliance). Oleh karena itu, kepatuhan wajib pajak merupakan faktor penting yang mempengaruhi realisasi penerimaan pajak.

Berdasarkan data KPP Pratama Depok Per 1 Juni 2015, bahwa jumlah wajib pajak orang pribadi yang terdaftar mengalami peningkatan setiap tahunnya hingga di tahun 2014 mencapai 241.518. Namun hanya 127.533 WPOP yang menyampaikan SPT. Berdasarkan data tersebut menyatakan bahwa tingkat kepatuhan WPOP yang menyampaikan SPT di tahun 2014 sebesar $53 \%$. Hal ini menandakan bahwa tingkat kepatuhan WPOP masih berfluktuasi dari tahun ke tahun, meskipun jumlah wajib pajak orang pribadi yang terdaftar mengalami peningkatan. Hal ini mengidentifikasi bahwasanya masih terjadi permasalahan terhadap kepatuhan wajib pajak dalam memenuhi kewajiban perpajakan.

Beberapa penelitian tentang kepatuhan pajak telah dilakukan oleh beberapa penelitian terdahulu. Muliari (2011) meneliti bahwa kesadaran, pelayanan fiskus berpengaruh positif terhadap kepatuhan wajib pajak. Kesadaran wajib pajak memiliki empat dimensi yakni: persepsi wajib pajak, pengetahuan perpajakan, karakteristik wajib pajak dan penyuluhan perpajakan. Wajib pajak dikatakan sadar untuk membayar pajak ketika ia memiliki pengetahuan yang cukup tentang perpajakan, memiliki karakteristik patuh dan telah mendapatkan penyuluhan yang memadai.

Nugraheni (2015) juga melakukan penelitian serupa dengan penelitian Muliari. Penelitian ini meneliti bahwa terdapat beberapa faktor yang mempengaruhi tingkat kepatuhan wajib pajak orang pribadi di Kota Magelang. Adapun faktor-faktor tersebut yakni kesadaran wajib pajak, pengetahuan dan pemahaman pajak, sanksi pajak, kualitas pelayanan fiskus pajak, keadilan distribusi, keadilan prosedural, dan keadilan interaksional. Berdasarkan hasil penelitian menyatakan bahwa keseluruhan variabel bebas berpengaruh positif dan signifikan terhadap kepatuhan wajib pajak oprang pribadi.

Penelitian ini mengkaji tingkat kepatuhan wajib pajak orang pribadi di Kota Depok dengan menggunakan beberapa variabel bebas yang juga pernah digunakan dalam penelitian sebelumnya seperti kualitas pelayanan fiskus, dimensi keadilan, dan kesadaran wajib pajak terhadap kepatuhan pajak orang pribadi. Dalam penelitian Nugraheni (2015), peneliti menggunakan pengetahuan dan pemahaman pajak sebagai salah satu variabel bebas. Namun, dalam penelitian ini pengetahuan dan pemahaman pajak tidak digunakan sebagai variabel bebas karena peneliti menganggap bahwa hal ini sebagai salah satu dimensi dari variabel kesadaran wajib pajak.

Dalam hal variabel keadilan, peneliti mengkhususkan menggunakan lima dimensi keadilan yakni keadilan umum, timbal balik pemerintah, struktur tarif pajak, ketentuanketentuan khusus dan kepentingan pribadi, berbeda dengan penelitian yang dilakukan oleh Nugraheni (2015) yang hanya menggunakan 3 dimensi keadilan yakni keadilan timbal balik pemerintah/keadilan distribusi, keadilan umum/ keadilan prosedural dan keadilan interaksional. Sehingga dalam mengetahui dimensi keadilan dapat lebih dalam. Berdasarkan deskripsi di atas, maka penulis tertarik untuk meneliti dan menganalisa pengaruh kualitas pelayanan fiskus, dimensi keadilan dan kesadaran wajib pajak terhadap tingkat kepatuhan pajak orang pribadi.

\section{Telaah Teori dan Pengembangan Hipotesis}

\section{Kepatuhan Pajak}

Muliari dan Setiawan (2011:5) mendefinisikan kepatuhan wajib pajak sebagai suatu keadaan dimana wajib pajak memenuhi semua kewajiban perpajakan dan melaksanakan hak perpajakannya. Wajib pajak yang patuh adalah wajib pajak yang taat memenuhi serta melaksanakan kewajiban perpajakan sesuai dengan peraturan perundang-undangan perpajakan. Pengertian Kepatuhan Perpajakan adalah sebagai suatu keadaan dimana Wajib Pajak memenuhi semua kewajiban perpajakan 
dan melaksanakan hak perpajakannya. Nurmantu (2003). Kepatuhan pajak tersebut menurut nurmantu ada 2 macam yaitu:

1. Kepatuhan Formal

Kepatuhan formal adalah suatu keadaan dimana Wajib Pajak memenuhi kewajibannya secara formal sesuai dengan dengan ketentuan dalam undang-undang perpajakan. Kepatuhan wajib pajak dalam membayar pajak secara formal dapat dilihat dari aspek kesadaran wajib pajak untuk mendaftarkan diri, ketepatan waktu dalam membayar pajak dalam menyampaikan SPT tahunan, ketepatan waktu dalam membayar pajak dan pelaporan wajib pajak melakukan pembayaran pajak dengan tepat waktu.

2. Kepatuhan Material

Kepatuhan Material adalah suatu keadaan dimana wajib pajak secara substantif (hakikat) memenuhi semua ketentuan material perpajakan yakni sesuai isi dan jiwa undang-undang perpajakan. Wajib Pajak yang memenuhi kepatuhan material dalam mengisi SPT $\mathrm{PPh}$ adalah Wajib Pajak yang mengisi dengan jujur, baik dan benar atas SPT tersebut sehingga sesuai dengan ketentuan dalam Undang-undang perpajakan dan menyampaikan SPT ke KPP sebelum batas waktu.

Pengertian kepatuhan pajak menurut Kiryanto dalam Jatmiko (2006) adalah:

a. Wajib pajak paham atau berusaha untuk memahami semua ketentuan peraturan perundang-undangan perpajakan;

b. Mengisi formulir pajak dengan lengkap dan jelas;

c. Menghitung jumlah pajak yang terutang dengan benar;

d. Membayar pajak yang terutang tepat pada waktunya.

\section{Kualitas Pelayanan Fiskus}

Nisa (2002) menyatakan bahwa pelayanan yang baik kepada wajib pajak akan membangun image positif dalam diri wajib pajak, sehingga mereka tidak lagi jera berhubungan dengan aparatur pajak. Kualitas pelayanan fiskus bisa dinilai dengan menggunakan indikator dari lima dimensi yaitu keandalan, jaminan, responsif, empati dan berwujud. Albari (2009) lima dimensi kualitas pelayanan fiskus tersebut adalah (1) keandalan (reliability), yaitu kemampuan untuk melaksanakan layanan yang dijanjikan secara tepat dan terpercaya, (2) jaminan (assurance), yaitu pengetahuan dan kesopanan santunan karyawan serta kemampuan organisasi dan karyawannya untuk menimbulkan kepercayaan dan keyakinan, (3) responsif (responsiveness), yaitu kemauan untuk membantu dan memberikan pelayanan dengan cepat kepada pelanggan, (4) empati (empathy), yaitu kepedulian atau perhatian pribadi yang diberikan organisasi kepada pelanggannya, dan (5) berwujud (tangibles), yaitu penampilan fisik, peralatan, personil dan media komunikasi.

\section{Dimensi Keadilan}

Syahdan dan Rani (2014) mengidentifikasi lima dimensi keadilan pajak yang mempengaruhi perilaku kepatuhan pajak, yaitu:

1. Keadilan Umum (General Fairness). Dimensi ini terkait dengan keadilan menyeluruh atas sistem perpajakan dan distribusi pajak.

2. Timbal balik Pemerintah (Exchange with Government). Dimensi ini terkait dengan timbal balik yang secara tidak langsung diberikan pemerintah atas pajak yang dibayarkan oleh Wajib Pajak.

3. Kepentingan Pribadi (Self-Interest). Dimensi ini terkait dengan apakah jumlah pajak yang dibayarkan Wajib Pajak secara pribadi terlalu tinggi dan jika dibandingkan dengan Wajib Pajak lainnya.

4. Ketentuan-ketentuan khusus (Special Provisions). Dimensi ini terkait ketentuanketentuan khusus yang diberikan kepada Wajib Pajak tertentu, misalnya insentif pengurangan tarif untuk perusahaan go public maupun UMKM. Dimensi ini 
merupakan penyederhanaan dua dimensi yang telah diidentifikasi oleh Richardson (2006), yaitu Attittude Towards Taxation of the Wealthy dan middle income earners tax share/burden.

5. Struktur Tarif Pajak (Tax Rate Structure). Dimensi ini terkait dengan struktur tarif pajak yang disukai (misalnya struktur tarif pajak progresif vs struktur tarif pajak flat/ proporsional).

\section{Kesadaran Wajib Pajak}

Muliari (2011) menyatakan kesadaran wajib pajak dengan empat dimensi, yaitu: persepsi wajib pajak, pengetahuan perpajakan, karakteristik wajib pajak dan penyuluhan perpajakan. Wajib pajak dikatakan sadar untuk membayar pajak ketika ia memiliki persepsi yang positif terhadap pajak, memiliki pengetahuan yang cukup tentang perpajakan, memiliki karakteristik yang patuh dan telah mendapatkan penyuluhan yang memadai.

Kesadaran wajib pajak atas perpajakan amatlah diperlukan guna meningkatkan kepatuhan wajib pajak. Secara empiris juga telah dibuktikan bahwa makin tinggi kesadaran perpajakan wajib pajak maka makin tinggi tingkat kepatuhan wajib pajak Jotopurnomo dan Mangoting (2013).

Dari beberapa literatur dan hasil penelitian didapatkan beberapa faktor internal yang dominan membentuk perilaku kesadaran Wajib Pajak untuk patuh yaitu :

1. Persepsi Wajib Pajak

Kesadaran Wajib Pajak untuk memenuhi kewajiban pajaknya akan semakin meningkat jika dalam masyarakat muncul persepsi positif terhadap pajak. Kesadaran pembayar pajak untuk patuh membayar pajak terkait dengan persepsi yang meliputi paradigma akan fungsi pajak bagi pembiayaan pembangunan, kegunaan pajak dalam penyediaan barang publik, juga keadilan (fairness) dan kepastian hukum dalam pemenuhan kewajiban perpajakan. Ketersediaan barang publik adalah masalah kepercayaan Wajib Pajak pada pemanfaatan pajak yang dibayar. Apabila Wajib Pajak merasa bahwa pajak yang dibayar tidak dapat dikelola dengan baik oleh Pemerintah, sehingga Wajib Pajak merasa tidak memperoleh manfaat yang nyata dari pajak yang dibayarnya, maka Wajib Pajak akan cenderung tidak patuh.

2. Tingkat pengetahuan terhadap ketentuan perpajakan yang berlaku

Tingkat pengetahuan dan pemahaman pembayar pajak terhadap ketentuan perpajakan yang berlaku berpengaruh pada perilaku kesadaran pembayar pajak. Wajib Pajak yang tidak memahami peraturan perpajakan secara jelas cenderung akan menjadi Wajib Pajak yang tidak taat, dan sebaliknya semakin paham Wajib Pajak terhadap peraturan perpajakan, maka semakin paham pula Wajib Pajak terhadap sanksi yang akan diterima bila melalaikan kewajiban perpajakannya.

3. Kondisi keuangan Wajib Pajak

Kondisi keuangan merupakan faktor ekonomi yang berpengaruh pada kepatuhan pajak. Kondisi keuangan adalah kemampuan keuangan perusahaan yang tercermin dari tingkat profitabilitas (profitability) dan arus kas (cash flow). Profitabilitas perusahaan (firm profitability) merupakan salah satu faktor yang mempengaruhi kesadaran untuk mematuhi peraturan perpajakan. Perusahaan yang mempunyai profitabilitas yang tinggi cenderung melaporkan pajaknya dengan jujur dari pada perusahaan yang mempunyai profitabilitas rendah. Perusahaan dengan profitabilitas rendah pada umumnya mengalami kesulitan keuangan (financial difficulty) dan cenderung melakukan ketidakpatuhan pajak. Demikian juga halnya dengan kondisi arus kas dengan likuiditasnya. 


\section{Metode Penelitian}

Populasi dalam penelitian ini adalah Wajib Pajak Orang Pribadi (WPOP) yang melakukan kegiatan usaha dan pekerjaan bebas yang berada di KPP Depok. Berdasarkan data dari KPP yang ada di KPP Kota Depok tercatat sebanyak 2.938 WPOP yang melakukan kegiatan usaha dan pekerjaan bebas aktif melapor. Untuk menghitung jumlah sampel yang dapat digunakan dalam penelitian ini, maka penulis menggunakan rumus Slovin dalam Sudrajat dan Ompusunggu (2015) sebagai berikut:

$$
n=\frac{N}{N \cdot e^{2}+1}
$$

Keterangan :

$\mathrm{n}=$ jumlah sampel

$\mathrm{N}=$ jumlah populasi

$\mathrm{e}=$ error (maksimal sebesar 10\%)
Berdasarkan data KPP Depok tercatat sebanyak 2.938 WPOP yang melakukan kegiatan usaha dan pekerjaan bebas aktif melapor. Oleh karena itu, jumlah sampel untuk penelitian dengan margin of error sebesar $10 \%$ adalah:

$$
\begin{aligned}
& n=\frac{2.938}{2.938(0.1)+1} \\
& n=96,71 \\
& n=100
\end{aligned}
$$

Berdasarkan perhitungan di atas, maka jumlah sampel yang harus dipenuhi dalam penelitian ini minimal sebanyak 96,71. Dalam penelitian ini, peneliti menyebarkan kuesioner sebanyak 110 lembar kepada Wajib Pajak Orang Pribadi.

\begin{tabular}{|c|c|c|c|c|c|}
\hline Variabel & Konsep Variabel & Indikator & Notasi & Skala & Indikator pertanyaan \\
\hline \multirow{7}{*}{$\begin{array}{l}\text { Kepatuhan } \\
\text { wajib pajak } \\
\text { (Y) }\end{array}$} & \multirow{7}{*}{$\begin{array}{l}\text { Kepatuhan Wp dalam } \\
\text { memenuhi kewajibannya } \\
\text { sesuai Undang-undang } \\
\text { perpajakan yang berlaku } \\
\text { maupun keadaan WP } \\
\text { memenuhi semua } \\
\text { ketentuan material } \\
\text { perpajakan. Numantu } \\
\text { dalam Widodo (2010) }\end{array}$} & $\begin{array}{l}\text { Pendaftaran wajib } \\
\text { pajak }\end{array}$ & KWP 1 & Skala likert & $\begin{array}{l}\text { Mendaftarkan diri sebagai wajib } \\
\text { pajak karena takut akan adanya sanksi } \\
\text { perpajakan }\end{array}$ \\
\hline & & \multirow[t]{2}{*}{$\begin{array}{l}\text { Penyampaian dan } \\
\text { pelaporan SPT }\end{array}$} & KWP 2 & Skala likert & $\begin{array}{l}\text { Tepat waktu dalam penyampaian SPT } \\
\text { ke kantor pajak }\end{array}$ \\
\hline & & & KWP 3 & Skala likert & Tepat waktu dalam menyetorkan pajak \\
\hline & & $\begin{array}{l}\text { Kesesuaian jumlah } \\
\text { kewajiban pajak yang } \\
\text { harus dibayar dengan } \\
\text { perhitungan sebenarnya }\end{array}$ & KWP 4 & Skala likert & $\begin{array}{l}\text { Membayar pajak sesuai dengan } \\
\text { perhitungan pajak yang sebenarnya }\end{array}$ \\
\hline & & $\begin{array}{l}\text { Kepercayaan terhadap } \\
\text { independensi akuntansi } \\
\text { publik konsultan pajak }\end{array}$ & KWP 5 & Skala likert & $\begin{array}{l}\text { Mempercayakan membayar pajak } \\
\text { kepada konsultan pajak dan saya } \\
\text { tidak mempengaruhi perhitungan dari } \\
\text { konsultan pajak }\end{array}$ \\
\hline & & \multirow{2}{*}{$\begin{array}{l}\text { Kemampuan petugas } \\
\text { pajak untuk melak- } \\
\text { sanakan layanan yang } \\
\text { dijanjikan secara tepat, } \\
\text { cepat dan terpercaya }\end{array}$} & KPF 1 & Skala likert & $\begin{array}{l}\text { Petugas pajak memberikan bimbingan } \\
\text { dan penyuluhan secara baik kepada } \\
\text { wajib pajak }\end{array}$ \\
\hline & & & KPF 2 & Skala likert & $\begin{array}{l}\text { Kecepatan dalam memproses dan } \\
\text { penyelesaian layanan oleh petugas } \\
\text { pajak }\end{array}$ \\
\hline & \multirow{3}{*}{$\begin{array}{l}\text { Suatu proses bantuan } \\
\text { kepada orang } \\
\text { lain dengan cara- } \\
\text { cara tertentu yang } \\
\text { memerlukan kepekaan } \\
\text { dan hubungan } \\
\text { interpersonal agar } \\
\text { tercipta kepekaan dan }\end{array}$} & Pemberian informasi & KPF 3 & Skala likert & $\begin{array}{l}\text { Informasi yang diberikan petugas pajak } \\
\text { dapat dipercaya }\end{array}$ \\
\hline Kualitas & & \multirow{2}{*}{$\begin{array}{l}\text { Kemampuan memban- } \\
\text { tu dan memberikan } \\
\text { pelayanan yang cepat } \\
\text { kepada pelanggan }\end{array}$} & KPF 4 & Skala likert & $\begin{array}{l}\text { Petugas pajak tanggap atas keluhan } \\
\text { yang disampaikan oleh wajib pajak }\end{array}$ \\
\hline $\begin{array}{l}\text { pelayanan } \\
\text { fiskus }(\mathrm{X} 1)\end{array}$ & & & KPF 5 & Skala likert & $\begin{array}{l}\text { Petugas pajak menguasai peraturan } \\
\text { perpajakan dan terampil dalam tugas- } \\
\text { tugasnya }\end{array}$ \\
\hline
\end{tabular}

Definisi Operasional dan pengukuran yang digunakan dalam penelitian ini diikhtisarkan sebagai berikut.

\section{Tabel 1. Definisi Operasional Variabel}


Pipit Awwalina, Suratno, JMV Mulyadi: Kualitas Pelayanan Fiskus, Dimensi...

keberhasilan. Kualitas pelayanan fiskus bisa dinilai dengan menggunakan indikator dari lima dimensi yaitu keandalan, jaminan, responsif, empati dan berwujud. Albari (2009)

Teori keadilan Rawls menitikberatkan pada bagaimana mendistribusikan hak dan kewajiban secara seimbang di masyarakat, sehingga setiap orang berpeluang untuk memperoleh manfaat dan menanggung Dimensi beban yang sama. Keadilan (X2) Terdapat lima dimensi keadilan pajak yang mempengaruhi perilaku kepatuhan pajak, yaitu keadilan umum, timbal balik pemerintah, kepentingan pribadi, Ketentuan-ketentuan khusus, struktur tarif pajak.

Syahdan dan Rani (2014)

Kesadaran pembayar pajak untuk patuh membayar pajak terkait dengan persepsi yang meliputi paradigma akan fungsi pajak bagi pembiayaan pembangunan, kegunaan pajak dalam penyediaan barang publik, juga

Kesadaran keadilan (fairness) dan

Wajib Pajak kepastian hukum dalam

(X3) pemenuhan kewajiban perpajakan. beberapa faktor internal yang dominan membentuk perilaku kesadaran Wajib Pajak untuk patuh yaitu persepsi wajib pajak, tingkat pengetahuan dan kondisi keuangan.

Jatmiko (2006)
Kepedulian atau perhatian pribadi yang diberikan organisasi kepada pelanggannya

Kemudahan pengisian dan penyampaian SPT

Sarana dan prasarana yang baik

$\mathrm{K}$ e $\mathrm{m}$ a $\mathrm{mpu}$ a $\mathrm{n}$

berkomunikasi

Sistem pajak dan pendistribusian diatur secara adil

Nilai manfaat yang

diterima sesuai dan adil

DK 3 Skala likert

-

perbandingan dengan

Wajib Pajak lain, pajak penghasilan yang

dibayarkan lebih sedikit

Ketidakadilan

pengurangan pajak

yang berlaku

Penentuan struktur tarif pajak

DK 4 Skala likert menjalankan aktivitas terkait dengan oulasi dan birokrasi, fasilitas-fasilitas umum

pajak penghasilan lebih sedikit daripada pembagian pajak penghasilan yang sesuai/ adil.

DK 5 Skala likert Pengurangan pajak berdasarkan peraturan yang berlaku tidak adil, karena hanya dapat digunakan oleh wajib pajak tertentu.

Skala likert

Penerima penghasilan tinggi memiliki suatu kemampuan untuk membayar pajak penghasilan lebih besar, sehingga wajar apabila mereka membayar pajak penghasilan lebih besar.

DK $7 \quad$ Skala likert Tarif pajak yang adil berarti harus sama untuk setiap Wajib Pajak.

Persepsi wajib pajak $\quad$ SWP $1 \quad$ Skala likert $\quad$ Pajak adalah sumber dana terbesar bagi negara

SWP 2 Skala likert Pajak berfungsi sebagai alat untuk mengatur atau melaksakan kebijakan di bidang sosial atau ekonomi, pajak sebagai sumber pembiayaan pembangunan, pajak sebagai alat pemerataan pendapatan

Tingkat Pengetahuan

SWP 3 Skala likert

Pengetahuan wajib pajak untuk memenuhi kewajiban pajak tepat waktu tanpa pengaruh orang lain

Kondisi Keuangan

SWP 4 Skala likert

Tetap taat membayar pajak sesuai dengan peraturan yang berlaku, bagaimanapun kondisi keuangan

Kejujuran dalam mengisi formulir sesuai dengan penghasilan yang saya hasilkan 
Pengujian hipotesis dilakukan dengan menggunakan model analisis regresi berganda bertujuan untuk memprediksi berapa besar kekuatan pengaruh variabel independen terhadap variabel dependen. Persamaan regresinya adalah:

$$
\text { Patuh }=\alpha+\beta 1 \text { Fiskus }+\beta 2 \text { Keadilan }+\beta 3 \text { Sadar }+\mathbf{e}
$$

Dimana :

$\begin{array}{lll}\text { Patuh } & : & \text { Kepatuhan Wajib Pajak } \\ \alpha & : & \text { Konstanta } \\ \beta 1, \beta 2, \beta 3: & \text { Koefisien regresi } \\ \text { Fiskus } & : & \text { Kepatuhan WP Terhadap } \\ & \text { Pelayanan Fiskus } \\ \text { Keadilan }: & \text { Kepatuhan WP terhadap } \\ & \text { Dimensi Keadilan } \\ \text { Sadar } \quad: & \text { Kepatuhan WP Terhadap } \\ & \text { Kesadaran Perpajakan } \\ \text { e } & : & \text { Residual }\end{array}$

Sementara itu, langkah-langkah untuk menguji pengaruh variabel independen, yaitu kualitas pelayanan fiskus dimensi keadilan dan kesadaran wajib pajak dilakukan dengan uji simultan dan uji parsial.

\section{Hasil dan Pembahasan}

Dalam penelitian ini, data diperoleh melalui kuesioner yang diberikan kepada wajib pajak pribadi yang menjalankan kegiatan usaha dan pekerjaan bebas yang terdaftar di KPP Pratama Depok. Pengumpulan data dalam penelitian ini dilakukan selama kurang lebih 3 bulan terhitung bulan April sampai Juni 2016. Karakteristik responden terdiri dari usia, jenis kelamin, jenis usaha pekerjaan bebas, tingkat pendidikan terakhir, dan pendapatan. Data tersebut terkumpul dari hasil survey terhadap 110 responden yang merupakan Wajib Pajak Orang Pribadi yang menjalankan usaha dan pekerjaan bebas di wilayah KPP Kota Depok.

Karakteristik responden berdasarkan usia dalam penelitian ini didominasi oleh responden yang usia 51-55 tahun (31\%) sebanyak 37 orang, usia 41-50 tahun (31,8\%) sebanyak 35 orang responden, usia 31-40 tahun (23,6\%) sebanyak 26 orang responden, usia kurang dari 30 tahun
(7,3\%) sebanyak 8 orang responden dan usia lebih dari 55 tahun $(3,6 \%)$ sebanyak 4 orang responden.

Karakteristik responden berdasarkan jenis kelamin dapat diketahui bahwa sebanyak 69 orang responden berjenis kelamin lakilaki $(62,7 \%)$ dan sisanya 41 orang responden berjenis kelamin perempuan $(37,3 \%)$. Hal ini menunjukkan bahwa responden dari Wajib Pajak Orang Pribadi yang menjalankan usaha dan pekerjaan bebas di KKP Depok sebagai sampel lebih banyak jenis kelamin laki-laki.

Karakteristik responden berdasarkan jenis usaha dan pekerjaan bebas di dominasi oleh 29 orang responden yang menjalankan usaha bebas dosen $(26,4 \%)$, usaha bebas lainnya yang terdiri Pemasar Asuransi atau Agen Asuransi, Konsultan Pajak, Arsitek dan akuntan Publik yaitu sebanyak 28 orang (25,5\%), sebanyak 24 orang responden yang menjalankan usaha bebas dokter (24\%), sebanyak 21 orang responden usaha bebas notaris $(19,1 \%)$, dan sebanyak 8 orang responden Profesional pengacara (7,3\%).

Karakteristik responden berdasarkan tingkat pendidikan terakhir, sebanyak 52 orang responden $(47,3 \%)$ memiliki pendidikan terakhir S1, sebanyak 39 orang responden (35,5\%) pendidikan terakhirnya adalah S2, kemudian sebanyak 14 orang $(12,7 \%)$ memiliki pendidikan terakhir diploma, sebanyak 4 orang responden (3,6\%) memiliki pendidikan terakhir S3 dan sebanyak 1 orang responden $(0,9 \%)$ memiliki pendidikan terakhir SMU/sederajat.

Karakteristik responden berdasarkan pendapatan perbulan di dominasi oleh responden yang memiliki pendapatan 6-10 juta yaitu sebanyak 42 orang $(38,2 \%)$. Sebanyak 33 orang responden memiliki pendapatan perbulan 11-15 juta (30\%), sebanyak 17 orang responden memiliki pendapatan per bulan 16-20 juta (15,5\%), sebanyak 12 orang responden memiliki pendapatan per bulan 0-5 juta (10,9\%), sebanyak 3 orang responden memiliki pendapatan per bulan 21-25 juta (2,7\%) dan sebanyak 3 orang responden dengan pendaptan perbulan lebih dari 25 juta $(2,7 \%)$. 
Tabel 2. Hasil Analisis Berganda

\section{Coefficients $^{\mathrm{a}}$}

\begin{tabular}{|c|c|c|c|c|c|c|}
\hline \multicolumn{2}{|c|}{ Model } & \multicolumn{2}{|c|}{$\begin{array}{l}\text { Unstandardized } \\
\text { Coefficients }\end{array}$} & \multirow{2}{*}{$\begin{array}{c}\text { Standardized } \\
\text { Coefficients } \\
\text { Beta }\end{array}$} & \multirow[t]{2}{*}{$\mathrm{t}$} & \multirow[t]{2}{*}{ Sig. } \\
\hline & & B & $\begin{array}{l}\text { Std. } \\
\text { Error }\end{array}$ & & & \\
\hline \multirow{4}{*}{1} & (Constant) & 1,066 & 1,249 & & 854 & ,395 \\
\hline & $\begin{array}{l}\text { Kualitas Pelayanan } \\
\text { Fiskal }\end{array}$ &, 144 & ,038 & ,266 & 3,819 &, 000 \\
\hline & Dimensi Keadilan &, 061 & 032 & ,137 & 1,866 &, 000 \\
\hline & Kesadaran Wajib Pajak & ,341 & 049 &, 531 & 7,011 &, 000 \\
\hline
\end{tabular}

a. Dependent Variable: kepatuhan Wajib Pajak

Berdasarkan tabel di atas, persamaan regresi menyatakan bahwa nilai konstan 1,066 berarti bahwa jika seluruh variabel independen dianggap konstan yaitu kualitas pelayanan fiskus, dimensi keadilan, dan kesadaran wajib pajak, maka nilai dependen yaitu kepatuhan wajib pajak akan sebesar 1,066. Nilai koefisien regresi kualitas pelayanan fiskus sebesar 0,144 berarti jika terjadi kenaikan 1 poin kualitas pelayanan fiskus maka nilai kepatuhan wajib pajak akan naik sebesar 0,144 atau semakin kompeten pelayanan fiskus. Nilai koefisien regresi dimensi keadilan sebesar 0,061 berarti jika terjadi kenaikan 1 poin dimensi keadilan maka nilai kepatuhan wajib pajak akan naik sebesar 0,061 atau semakin adil dimensi keadilan pajak. Nilai koefisien regresi kesadaran wajib pajak sebesar 0,341 berarti jika terjadi kenaikan 1 poin kesadaran wajib pajak maka nilai kepatuhan wajib pajak akan naik sebesar 0,341 atau semakin sadar wajib pajak terhadap pajak.

Nilai koefisien determinasi sederhana $\left(\mathrm{R}^{2}\right)$ sebesar 0,547 , artinya ada hubungan kuat antara variabel bebas kualitas pelayanan fiskus, dimensi keadilan dan kesadaran wajib pajak terhadap variabel terikat kepatuhan wajib pajak. Nilai ini menunjukkan bahwa 54,7\% kepatuhan wajib pajak di Kota Depok dipengaruhi oleh variabel kualitas pelayanan fiskus, dimensi keadilan dan kesadaran wajib pajak. Sedangkan sisanya sebesar $45,3 \%$ dipengaruhi oleh variabel lainnya.

Nilai sebesar 44,856. Jika dibandingkan dengan pada tingkat signifikansi $5 \%$ yaitu sebesar 2,69 $\left(\mathrm{df}_{1}=3\right.$, dan $\left.\mathrm{df}_{2}=106(\mathrm{n}-\mathrm{k}-1)\right)$. Dikarenakan nilai $\mathrm{F}$ hitung $>\mathrm{F}$ tabel $(44,856>2,69)$ maka $\mathrm{H}_{0}$ ditolak. Nilai sig. sebesar 0,000 pada tabel di atas menunjukkan bahwa pengaruh variabel kualitas pelayanan fiskus, dimensi keadilan dan kesadaran wajib pajak terhadap kepatuhan wajib pajak signifikan. Hal ini disebabkan nilai sig. 0,000 lebih kecil dari nilai $\boldsymbol{\alpha}=\mathbf{0 , 0 5}$. Berdasarkan uji hipotesis tersebut dapat disimpulkan bahwa variabel kualitas pelayanan fiskus, dimensi keadilan dan kesadaran wajib pajak berpengaruh positif dan signifikan terhadap kepatuhan wajib pajak. Dengan demikian, dapat diketahui bahwa terdapat pengaruh positif dan signifikan antara kualitas pelayanan fiskus, dimensi keadilan dan kesadaran wajib pajak terhadap kepatuhan wajib pajak orang pribadi dalam membayar pajak di KPP Kota Depok.

\section{Pengaruh Kualitas Pelayanan Fiskus, Dimensi Keadilan dan Kesadaran Wajib Pajak Terhadap Kepatuhan Wajib Pajak}

Hasil penelitian menunjukkan bahwa $\mathrm{H}_{\text {。 }}$ ditolak dan Ha diterima. Hal ini berarti bahwa kualitas pelayanan fiskus, dimensi keadilan dan kesadaran wajib pajak berpengaruh terhadap kepatuhan wajib pajak. Kualitas pelayanan fiskus, dimensi keadilan dan kesadaran wajib 
pajak merupakan faktor yang penting dalam meningkatkan kepatuhan wajib pajak. Kualitas pelayanan fiskus yang baik dari instansi pajak dapat menjadi modal utama dan menjadi hal yang penting untuk dapat menarik perhatian dan manimbulkan kepercayaan dari wajib pajak. Apabila wajib pajak mendapat pelayanan terbaik serta timbul rasa percaya kepada instansi pajak maka akan terjadi peningkatan pada kepatuhan wajib pajak. Dimensi keadilan yang baik akan menumbuhkan kepercayaan wajib pajak terhadap perpajakan. Apabila wajib pajak merasa bahwa perpajakan di Indonesia sudah adil, baik mengenai tarif pajak maupun hasil yang dirasakan maka akan dapat meningkatan kepatuhan wajib pajak. Kesadaran wajib pajak diperlukan untuk memahami dan sadar bahwa membayar pajak adalah kewajiban warga indonesia. Apabila tingkat pengetahuan pajak, persepsi wajib pajak mengenai pentingnya membayar pajak dan kondisi keuangan bagaimana pun wajib pajak akan membayar pajak maka akan meningkatkan kepatuhan wajib pajak. Semakin tinggi kualitas pelayanan fiskus, dimensi keadilan dan kesadaran wajib pajak maka akan semakin tinggi pula tingkat kepatuhan wajib pajak.

Dari ketiga variabel bebas tersebut menunjukkan bahwa variabel kesadaran wajib pajak memiliki pengaruh yang paling besar terhadap kepatuhan wajib pajak, kemudian variabel kedua adalah kualitas pelayanan fiskus, selanjutnya adalah variabel dimensi keadilan. Hal ini mengandung makna variabel kesadaran wajib pajak terhadap kepatuhan wajib pajak meliputi aspek persepsi wajib pajak terhadap pentingnya kewajiban membayar pajak, tingkat pengetahuan wajib pajak terhadap pajak dan kondisi keuangan merupakan faktor yang sangat menentukan dalam melaksanakan kepatuhan dibandingkan dengan variabel kualitas pelayanan fiskus dan dimensi keadilan.

\section{Pengaruh Kualitas Pelayanan Fiskus Terhadap Kepatuhan Wajib Pajak}

Dalam penelitian ini kualitas pelayanan fiskus diukur dengan indikator kemampuan petugas pajak, pemberian informasi, kemampuan membantu dan memberikan pelayanan, kepedulian, kemudahan pengisian SPT, sarana dan prasarana dan kemampuan berkomunikasi. Dengan demikian ketujuh indikator tersebut berpengaruh dalam meningkatkan kepatuhan wajib pajak, artinya (1) semakin baik kemampuan petugas pajak untuk melaksanakan layanan yang dijanjikan secara cepat dan terpercaya, (2) semakin baik pemberian informasi yang cepat dan akurat, (3) semakin kompeten kemampuan petugas pajak dalam membantu dan memberikan pelayanan yang cepat kepada pelanggan, (4) semakin lebih baik perhatian pribadi yang diberikan petugas pajak terhadap wajib pajak, (5) semakin mudah dalam mengisi dan menyampaikan SPT, (6) semakin baik sarana dan prasarana, dan (7) semakin handal kemampuan petugas pajak dalam berkomunikasi.

Pelayanan pajak berupa fasilitas fisik dan pelayanan dari petugas pajak yang baik dapat membuat tingkat kepatuhan wajib pajak meningkat. Fasilitas fisik seperti ruang tunggu, tempat parkir yang cukup luas, formulir pajak yang tersedia secara lengkap membuat wajib pajak merasa nyaman saat berada di kantor pajak. Selain fasilitas fisik yang nyaman, berbagai macam kegiatan yang mendukung wajib pajak untuk dapat lebih mudah melaksanakan kewajibannya membayar pajak antara lain petugas pajak cakap dalam menindaklanjuti pengaduan dari masyarakat, petugas pajak cepat tanggap dalam membantu menyelesaikan persoalan yang dihadapi wajib pajak terkait dengan pajak, petugas pajak memberikan pelayanan terbaik dalam memberikan kemudahan dalam pelayanan pajak, serta petugas pajak yang dapat menjunjung tinggi integritas, akuntabilitas, dan transparansi dapat menimbulkan kepercayaan dari wajib 
pajak. Apabila sudah terdapat kepercayaan dari wajib pajak, maka wajib pajak tidak lagi merasa enggan untuk melaksanakan kewajibannya membayar.

Penelitian ini sejalan dengan penelitian yang dilakukan Supadmi (2010) disebutkan bahwa untuk meningkatkan kepatuhan wajib pajak dalam memenuhi kewajiban perpajakannya, kualitas pelayanan pajak harus ditingkatkan oleh aparat pajak. Pelayanan fiskus yang baik akan memberikan kenyamanan bagi wajib pajak. Keramahtamahan petugas pajak dan kemudahan dalam sistem informasi perpajakan termasuk dalam pelayanan perpajakan tersebut. Hal inilah yang akan menyebabkan wajib pajak dapat bersikap patuh terhadap pajak. Penelitian Jatmiko (2006) menemukan bahwa pelayanan fiskus memiliki pengaruh positif yang signifikan terhadap kepatuhan wajib pajak.

\section{Pengaruh Dimensi Keadilan Terhadap Kepatuhan Wajib Pajak}

Dalam penelitian ini, variabel dimensi keadilan diukur dengan 5 indikator, yakni sistem pajak dan pendistribusian diatur secara adil, nilai manfaat yang diterima sesuai dan adil, perbandingan dengan wajib pajak lain, ketidakadilan pengurangan pajak yang berlaku dan penentuan struktur tarif pajak. Hal ini menitikberatkan pada bagaimana mendistribusikan hak dan kewajiban secara seimbang di masyarakat sehingga setiap orang berpeluang untuk memperoleh manfaat dan menanggung beban yang sama.

Hasil penelitian ini tidak sesuai dengan penelitian terdahulu yang dilakukan oleh Pris (2010) melakukan penelitian dengan variabel bebas lima dimensi keadilan, yakni yakni keadilan umum (general fairness), timbal balik pemerintah (exchange with the government), struktur tarif pajak (tax rate structure), ketentuan-ketentuan khusus (special provisions), dan kepentingan pribadi (self interest). Adapun variabel terikat adalah perilaku kepatuhan pajak badan. Hasil penelitian menyatakan bahwa dimensi keadilan umum, dimensi timbal balik pemerintah, dimensi kepentingan pribadi, dimensi ketentuan-ketentuan khusus dan dimensi struktur tarif pajak tidak berpengaruh signifikan terhadap kepatuhan pajak badan.

Perbedaan hasil penelitian ini disebabkan oleh perbedaan subjek yang diteliti, dalam penelitian Pris dilakukan pada kepatuhan wajib pajak badan. Di mana kepatuhan wajib pajak badan tidak berpengaruh terhadap dimensi keadilan. Dimensi keadilan pajak, dalam bentuk keadilan umum berpengaruh terhadap kepatuhan WPOP di KPP Kota Depok. Perilaku kepatuhan ini karena adanya sistem pajak penghasilan yang diatur secara adil, cara pembebanan pajak penghasilan didistribusikan secara adil kepada wajib pajak, dan pajak yang dibebankan dilakukan secara adil. Selain itu, pajak yang dikenakan kepada wajib pajak sebanding dengan kemampuan membayar pajak. Hasil pengujian ini mendukung penelitian yang dilakukan Syahdan dan Rani (2014) yang menyatakan bahwa dimensi keadilan umum berpengaruh signifikan terhadap perilaku kepatuhan di Malaysia. Dimensi keadilan pajak, dalam bentuk timbal balik dari pemerintah ini karena adanya nilai manfaat yang sesuai dan adil dari pemerintah atas pembayaran pajak. Timbal balik yang diberikan pemerintah sebagai kompensasi pembayaran pajak, wajib pajak berharap bahwa membayar pajak dapat memajukan kehidupannya, dimana wajib pajak berharap saat pajak yang dibayarkan serta merta diikuti perbaikan pelayanan publik dan birokrasi.

\section{Pengaruh Kesadaran Wajib Pajak Terhadap Kepatuhan Wajib Pajak}

Dalam penelitian ini, variabel kesadaran wajib pajak diukur dengan 3 indikator, yakni persepsi wajib pajak, tingkat pengetahuan dan kondisi keuangan. Hal ini berarti kesadaran wajib pajak untuk patuh membayar pajak terkait persepsi yang meliputi paradigma akan fungsi pajak bagi pembiayaan pembangunan, kegunaan pajak dalam penyediaan barang publik, juga 
keadilan dan kepastian hukum dalam pemenuhan kewajiban perpajakan.

Penelitian ini sejalan dengan penelitian Muliari (2011) melakukan penelitian dengan variabel bebas yakni kesadaran, pelayanan dan kepatuhan wajib pajak. Sedangkan variabel terikat adalah kinerja penerimaan pajak. Berdasarkan hasil penelitian Suryadi menyatakan bahwa Kesadaran wajib pajak memiliki empat dimensi yaitu: persepsi wajib pajak, pengetahuan perpajakan, karakteristik wajib pajak dan penyuluhan perpajakan. Wajib pajak dikatakan sadar untuk membayar ketika ia memiliki pengetahuan yang cukup tentang perpajakan, memiliki karakteristik patuh dan telah mendapatkan penyuluhan yang memadai.

\section{Simpulan, Keterbatasan, dan Saran}

Berdasarkan hasil pengujian ditemukan bahwa model terbuktifit (baik). Pengaruh masingmasing variabel dalam hipotesis penelitian dapat disimpulkan bahwa terdapat pengaruh yang signifikan antara kualitas pelayanan fiskus, dimensi keadilan, dan kesadaran wajib pajak terhadap tingkat kepatuhan wajib pajak secara simultan. Berdasarkan nilai adjusted $\mathrm{R}^{2}$ adalah sebesar 0,547 atau $54,7 \%$. Dengan demikian maka kualitas pelayanan fiskal, dimensi keadilan dan kesadaran wajib pajak memberikan pengaruh terhadap kepatuhan wajib pajak secara simultan sebesar $54,7 \%$. Sedangkan sisanya $45,3 \%$ merupakan pengaruh dari variabel lain yang tidak diteliti.

Dalam penelitian ini memiliki keterbatasanketerbatasan, yakni penelitian ini hanya meneliti pengaruh dari variabel pelayanan fiskus, dimensi keadilan dan kesadaran wajib pajak terhadap variabel dependen kepatuhan wajib pajak orang pribadi dalam membayar pajak melakukan kegiatan usaha dan pekerjaan bebas aktif melapor di KPP Kota Depok tahun 2015. Pengumpulan data pada penelitian ini dilakukan dengan kuesioner, sehingga data yang dikumpulkan hanya menggambarkan pendapat wajib pajak sebagai objek penelitian. Penelitian ini hanya dilakukan selama satu periode saja yaitu tahun pajak 2015.

Secara simultan dan parsial terhadap pengaruh kualitas pelayanan fiskus, dimensi keadilan dan kesadaran wajib pajak terhadap kepatuhan wajib pajak, sehingga pembuat kebijakan dan fiskus perlu mengetahui faktorfaktor yang mempengaruhi kepatuhan wajib pajak. Hal ini diperlukan agar lebih meningkatkan kualitas pelayanan, dan kesadaran dalam melaksanakan tugas fiskus melalui sosialisasi dan workshop kepada wajib pajak.

Sebagaimana dijelaskan sebelumnya, hasil penelitian menunjukkan hubungan antara kualitas pelayanan fiskus, dimensi keadilan dan kesadaran wajib pajak terhadap kepatuhan wajib pajak. Secara teoritis, hal ini dapat mendorong arah riset selanjutnya untuk lebih spesifik meneliti faktor-faktor yang mempengaruhi kepatuhan wajib pajak sehingga dapat menghasilkan teori baru khususnya dalam rangka meningkatkan kepatuhan wajib pajak.

\section{Daftar Referensi}

Albari, A. (2009). Pengaruh Kualitas Layanan Terhadap Kepatuhan Membayar Pajak. Jurnal Fakultas Hukum UII, 13(1).

Jatmiko, A. N. (2006). Pengaruh Sikap Wajib Pajak pada Pelaksanaan Sanksi Denda, Pelayanan Fiskus dan Kesadaran Perpajakan terhadap Kepatuhan Wajib Pajak (Studi Empiris terhadap Wajib Pajak Orang Pribadi di Kota Semarang) (Doctoral dissertation, Program Pasca Sarjana Universitas Diponegoro).

Jotopurnomo, C., \&Mangoting, Y. (2013). Pengaruh kesadaran wajib pajak, kualitas pelayanan fiskus, sanksi perpajakan, lingkungan wajib pajak berada terhadap kepatuhan wajib pajak orang pribadi di Surabaya. Tax \& Accounting Review, 1(1), 49.

Muliari, N. K., \& Setiawan, P. E. (2011). 
Pengaruh persepsi tentang sanksi perpajakan dan Kesadaran wajib pajak pada kepatuhan Pelaporan wajib pajak orang pribadi di kantor Pelayanan pajak pratama denpasar timur. Jurnal Ilmiah Akuntansi dan Bisnis. Nisa, H. (2002). Hubungan antara Tingkat Pendidikan Wajib Pajak dan Efektifitas Layanan Informasi Perpajakan terhadap Sikap Ketaatan Wajib Pajak dalam Membayar Pajak di Kecamatan Kepon, Kabupaten Blora, Jawa Tengah. Skripsi. Fakultas Ekonomi Universitas Muhammadiyah Surakarta. Tidak Dipublikasikan.

Nugraheni, A. D., \&Purwanto, A. (2015). Faktor-Faktor yang Mempengaruhi Kepatuhan Wajib Pajak Orang Pribadi (Studi Empiris pada Wajib Pajak di Kota Magelang) (Doctoral dissertation, Fakultas Ekonomika dan Bisnis).

Nurmantu, S. (2005). Pengantar perpajakan. Yayasan Obor Indonesia.
Pris K, A., \& Kiswara, E. (2010). Dampak dimensi keadilan pajak Terhadap tingkat kepatuhan wajib Pajak badan(Doctoral dissertation, Universitas Diponegoro).

Sudrajat, A., \&Ompusunggu, A. P. (2015). Pemanfaatan teknologi Informasi, Sosialisasi Pajak, Pengetahuan Perpajakan, dan Kepatuhan Pajak. JRAP (Jurnal Riset Akuntansi dan Perpajakan), 2(2).

Susmita, P. R., \&Supadmi, N. L. (2016). Pengaruh Kualitas Pelayanan, Sanksi Perpajakan, Biaya Kepatuhan Pajak, Dan Penerapan E-Filing Pada Kepatuhan Wajib Pajak. E-Jurnal Akuntansi, 1239-1269.

Syahdan, S. A., \& Rani, A. P. (2014). Dimensi Keadilan atas Pemberlakuan PP No. 46 Tahun 2013 dan Peningkatan Kepatuhan Wajib Pajak. InFestasi, 10(1), 64-72.

Widodo, W., Djefris, D., \&Wardhani, E. A. (2010). Moralitas, Budaya, dan Kepatuhan Pajak. Alfabeta. 